\title{
Increasing Entrepreneurship Ability of Student of Sport Science Faculty
}

\author{
${ }^{1}$ Nurul Ihsan, ${ }^{2}$ Sepriadi, ${ }^{3}$ Suwirman \\ ${ }^{123}$ Fakultas Ilmu Keolahragaan, Universitas Negeri Padang, Indonesia \\ Email: dr.nurulihsan.mpd@gmail.com ${ }^{1}$, sepriadi@fik.unp.ac.id ${ }^{2}$, suwirmanmaketek@gmail.com $^{3}$
}

\begin{abstract}
The main problem in this activity is that the students' abilities are not maximal in relation to entrepreneurship. The main problem lies in the managerial ability of business, administration, product quality and other matters related to entrepreneurship. This is because students involved in this program do not have in-depth understanding and knowledge related to business management. In addition, the process carried out when obtaining funding was not too developed due to the relatively insufficient funding aspect. To overcome this problem, programs are compiled which will be implemented in 3 patterns, namely training, mentoring and mentoring. The type of training that will be provided is hard skills and soft skills training related to entrepreneurship development. The targets of this activity are students who receive grants from the Entrepreneurship Scheme Student Creativity Program and the Student Entrepreneurship Program. Besides that, there are also students who are interested in developing entrepreneurship. This activity was carried out at the Faculty of Sport Sciences, State University of Padang. Implemented from August to October 2020. In accordance with the objectives of this Community Service, the approach pattern to be carried out uses the Participation Actions Learnig System (PALS) pattern. This pattern is a pattern where tenants participate directly in every program that will be provided. The results obtained from the activity: 1) Increase the ability of participants related to entrepreneurial soft skills, 2) Increase the ability of participants related to entrepreneurial hard skills.
\end{abstract}

Keywords: Students, Entrepreneurship

\section{Abstrak}

Permasalahan utama dalam kegiatan ini adalah belum maksimalnya kemampuan mahasiswa berkaitan dengan kewirausaahan. Permasalahan utama terletak pada kemampuan manajerial bisnis, pengadministrasian, kualitas produk sertahal-hal lain yang berhubungan dengan kewirausahaan. Hal ini dikarenakan mahasiswa yang terlibat dalam program ini tidak memiliki pemahaman dan pengetahuan yang mendalam terkait pengelolaan bisnis. Selain itu, proses yang dilakukan saat mendapatkan pendanaan tidak terlalu berkembang dikarenakan aspek pendanaan yang relatif kurang. Untuk mengatasi masalah tersebut, maka disusun program-program yang akan dijalankan dalam 3 pola, yaitu Pelatihan, pembimbingan dan pendampingan. Jenis pelatihan yang akan diberikan adalah pelatihan-pelatihan hardskill dan softskill terkait pengembangan kewirausahaan. Sasaran kegiatan ini adalah mahasiswa penerima program hibah Program Kreatifitas Mahasiswa Skema Kewirausahaan dan Program Kewirausahaan Mahasiswa. Selain itu juga mahaiswa yang berminat mengembangkan kewirausahaan. Kegiatan ini dilaksanakan di Fakultas Ilmu Keolahragaan Universitas Negeri Padang. Dilaksanakan pada Agustus hingga bulan Oktober tahun 2020. Sesuai dengan tujuan dilaksanakan Pengabdian ini, maka pola pendekatan yang akan dilakukan menggunakan pola Participation Actions Learnig System (PALS). Pola ini merupakan pola dimana tenant berpartisipasi langsung dalam setiap program yang akan berikan. Hasil yang diperoleh dari kegiatan: 1) Peningkatan kemampuan peserta terkait softskill kewirausahaan, 2) Peningkatan kemampuan peserta terkait hard skill kewirausanaan.

Keywords: Mahasiswa, Wirausaha

\section{ANALISIS SITUASI}

Covid 19 memberikan dampak keberbagai lini serta spek masyarakat. Salah satunya adalah pada aspek ekonomi. Banyak karyawan di PHK yang berimbas pada lumpuhnya perekonomian masyarakat. Selain itu, usha masyarakat juga banyak yang tutup. Rata-rata seluruh sektor perekonomian merasakandampak dari covid 19. Imbas lain dari covid 19 ini adalah pada mahasiswa 
UNP yang secara tidak langsung masih bergantung pada keluarga dan orang tua. UNP segagai lembaga LPTK memberikan berbagai solusi permaslahanyang dihadapi oleh mahsaiswa. Salah satunya adalah dengan memberikan dorongan kepada mahasiswa yang berkeinginan dan memiliki kemamuan yang kuat dalam berwirusaha. Dan tentunya, usaha tersebut merupakan usaha yang sangant relevan dengan keahlian dan kondisi saat ini. Salah satui programyang sekaran dikembangkan adalah Program Mahasiswa Wirausaha (PMW). Sejak tahun 2009, UNP telah melaksanakan pembinaan mahsiswa dalam, berwirausaha dalam bentuk Program Mahasiswa Wirausaha (PMW). Setiap tahunnya, UNP mengalokasikan anggaran rata-rata $\mathrm{Rp}$. 400.000.000,- per tahun dalam mengembangkan jiwa kewirausahaan mahasiswa.

Berbagai jenis kewirausahaan yang dikembangkan oleh UNP. Rata-rata jumlah mahasiswa yang terlibat dalam PMW ini berjumlah 500 orang pertahun. Jumlah ini tersebar di 8 Fakultas yang ada di UNP. Selain itu, UNP juga telah melaksanakan Program Kreatifitas Mahasiswa (PKM). Program ini mampu menyerap berbagai jenis proposal kewirausahaan mahasiswa. Khususnya Fakultas Ilmu Keolahragaan (FIK) jurusan Pendidikan Olahraga, jumlah mahasiswa yang berhasilkan mendapatkan pendanaan PKM dan PMW rata tiap tahun ada 2-3 judul. Jumlah mahasiswa yang terlibat 1 0-15 orang. Jenis usaha yang dihasilkan pun beragam.

Mulai dari wirausaha kuliner, konveksi hingga jasa. Sama halnya dengan ketentuan nasional, PMW dan PKM yang didanai 5 UNP juga dievaluasi dan di montoring dalam rangka pengukuran pencapaian kemajuan. Bahan evalasi tersebut selanjutnya akan dipergunakan menentukan apakah kegiatan ini dilanjutkan atau dihentikan. Dari berbagai jenis usaha yang dijalankan oleh mahasiswa penerima program PMW dan PKM bidang kewirausahaan. Dari sisi pendanaan yang diberikan pada masing-masing kelompok penerima, rata-rata dalam satu tahun setiap kelompok mendapatkan 12-15 juta per jenis usaha. Sifat pendanaan berkesinambungan.

Artinya bagi usaha yang berhasil memenuhi target dan dianggap memiliki prospek berkembang, maka akan diberikan bantuan pendanaan tahun berikutnya. Program ini maksimal berjalan 3 tahun pendanaan. Namun, jika kelompok usaha tersebut dianggap kurang memenuhi target dan tidak memiliki prospek untuk berkembang, maka pendanaan akan dihentikan pada tahun pertama. Dari sekian banyak kelompok yang didanai, pada akhir tahun yang mampu bertahan tidak lebih dari 15 $\%$. Dari sekian banyak jenis usaha yang dijalankan, rata-rata hanya mampu bertahan pada tahun pertama. Bahkan ada juga beberapa kelompok usaha tidak berjalan hingga akhir tahun pertama.

Data ini terlihat dari hasil monitoring dan evaluasi yang dilakukan oleh tim PMW dan PKM kewirausahaan UNP. Kondisi ini juga terjadi pada kelompok usaha yang dijalankan oleh mahasiswa Fakultas Ilmu Keolahragaan. Berbagai jenis usaha yang dijalankan banyak yang tidak berhasil mencapai target yang dijanjikan. Kondisi ini sangat disayangkan. Hal ini karenakan potensi usaha yang dilaksanakan sangat menjanjikan jika dikelola dengan baik. Seperti usaha masase yang dijalankan oleh mahasiswa, potensinya terletak pada kemampuan dalam keilmuan yang didukung oleh iptek dan komptensi yang pernah dibekali. Masase merupakan salah satu mata kuliah yang idwajibkan kepada setiap mahasiswa..

Berikut beberapa kondisi yang ditemui terkait pelaksanaan PMW di Universitas Negeri Padang, khususnya pada Fakultas Ilmu Keolahragaan: 1). Usaha jasa masase Anggotanya adalah para tim massure PON Sumbar. Secara kemampuan atau keahlian dalam memassage, meraka sangat baik. Hal ini dikarenakan meraka merupakan anggota tim kesehatan di beberapa tim olahraga di Sumatera Barat. Namun dalam hal pengelolaan usaha meraka sangat kurang. Sehingga order tidak terlayani secara baik. Dari sisi kualitas pelayanan, teknik komunikasi dan lain sebagainya masih perlu dibina. 2). Usaha privat beladiri Usaha privat beladiri anggotanya terdiri atas 5 orang atlet ( 3 putera dan 2 puteri).

Kesemua anggota tim usaha ini adalah atlet Pencak Silat PON Sumbar dan tim pernah menjadi atlet Pelantnas Indonesia (Sea Games 2004, 2015, 2016 dan 2017). Artinya dari sisi kemampuan, masing-masing anggota memiliki keahlian dalam usaha yang dijalankan. Namun usaha ini tidak berjalan dengan baik. Kondisi diawal pelaksanaan member telah banyak, namun dikarenakan kemampuan dalam adminsitrasi dan pengembangan usaha serta pengelolaan keuangan kurang baik, maka akhirnya usaha ini juga tidak berjalan sebagai mana mestinya. 3). Sovenir Usaha yang dijalankan oleh mahasiswa FIK dalam bidang sovenir. Produk yang dihasilkan kurang menarik dan kurang dapat bersaing dengan home insdustri yang ada di daerah sekitar usaha, sehingga kalah 


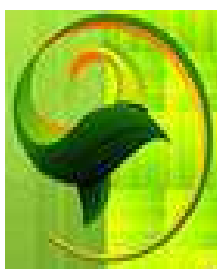

Journal Humanities: Jurnal Pengabdian kepada Masyarakat

Volume 1, Nomor 2, Bulan Desember, 2020.

E - ISSN 2715-5471

Doi: https://doi.org/10.24036/jha.02.01.2020.11

berasing. Misalnya Mug, Gantungan Kunci serta slempang wisuda belum bias bersaing dengan produk lain.

Berangkat dari permasalahan tersebut, maka kami dari tim menjadi terpanggil untuk memberikan solusi-solusi dan bantuan terkait permasalahan yang dihadapi para mahasiswa dan Alumni FIK yang sedang menjalankan usaha. Sehingga diharapkan para mahasiswa dan Alumni FIK yang sedang menjalankan usaha mampu mencapai hasil yang sesuai dengan yang diharapkan. Tim yang tergabung dalam kegiatan ini adalah para dosen yang telah membina dan menjadi pembimbing dalam berbagai kegiatan kewirausahaan mahasiswa di UNP.

Khususnya ketua pelaksana merupakan salah satu anggota tim yang membina kelompok pemuda dikawasan wisata dalam hal pengembangan usaha kerajinan tangan. Ketua dan anggota tim merupakan dosen yang telah memiliki sertifikat pendampingan kewirausahaan yang dikeluarkan oleh Badan Nasional Standar Profesional (BSNP) Sehingga kami merasa yakin dan mampu memberikan 7 solusi yang terbaik dalam memecahkan permasalahan yang dihadapi mahasiswa dan Alumni FIK dalam menjalankan usahanya.

\section{SOLUSI DAN TARGET}

Berdasarkan penelusuran dan diskusi serta pengamatan selama menjadi pembimbing Program kewirausahaan mahasiswa Jurusan Pendidikan Olahraga, persoalan yang dihadapi oleh tenant dapat dikelompokkan menjadi 3 aspek yaitu softskill, hardskill dan pengalaman. Sesuai dengan permasalahan yang dihadapi para calon tenant tersebut, maka dapat dikemukakan beberapa solusi yang dapat mengatasi permasalahan pada calon tenant, yaitu:

a. Pelatihan softskill dan hard skill wirausaha Pelatihan ini akan melibatkan para pemateri yang sudah memiliki lesinsi sebagai mentor dan morivatir dakam pembinaan hard skill dan soft skil dalam pengembangan minsite, pola pikir, visi dan misi usaha serta tim work serta pengembangan jejaring bisnis. Luaran dari pelatihan soft skill mahasiswa adalah lahirnya mahasiswa yang memiliki keterampilan soft skill yang baik. Ini dibuktikan dengan adanya hasil tes ataupun seritifikasi di bidang soft skiil dan hard skill yang dilatih.

b. Pelatihan tentang peningkatan kualitas produk Palatihan ini akan melibatkan para penggelut usaha sejenis yang memiliki reputasi dan kapabilitas terkait produk yang dikembangkan. Selain itu, juga akan melibatkan pakar dari dinas industri perdagangan dan koperasi yang membawahi pembinaan wirausahawan muda. Luaran dari pelatihan ini adalah evaluasi tertulis terkait pemahaman tenant setelah mendapatkan pelatihan tentang peningkatan kualitas produk. Selain itu dibuktikan adanya produk inovasi terbaru yang dihasilkan oleh tenant dari pelatihan

c. Pelatihan tentang pemanfaatan teknologi Pemanfaatan IT dalam hal promosi usaha serta sentuhan teknologi dalam produk yang dikembangkan. Misalnya pada produk beladiri. Ini sesuai dengan keahlianketua tim pengusul yang telah banyak melakukan pengembangan instrumen dalam olahraga yang berbasis IT. Salah satunya adalah alat ukur kecepatan tendangan berbasis digital. luaran pelatihan ini diharapkan masing-masing tenant minimal telah memiliki blog sebagai wadah pemasaran secara online.

d. Pelatihan tentang pengadministrasian usaha Pelatihan ini lebih mengarah pada pembukuan, keuangan serta lain sebagainya terkait persoalan adminstrasi. Selain itu juga akan diberikan pula materi terkait pengurusan izin usaha, seperti SIUP dan SITU. Luaran dari pelatihan ini adalah masing-masing tenant telah terdaftar sebagai UKM yang memiliki izin usaha dariinstansi terkait.

e. Magang usaha Magang akan dilakukan di perusahaan-perusahaan, lembaga, kelompok usaha dan lain sebagainya yang memiliki kesamaan dengen produk yang dikembangkan. Fokus utama pada pengelolaan usaha. Luaran dari kegiatan magang usaha adalah laporan secara tertulis oleh masingmasing tenant.

f. Studi banding Studi banding dilakukan di perusahaan-perusahaan, lembaga, kelompok usaha yang telah berskala nasional dan ternama. Targetnya adalah sebagai bahan perbandingan dengan usaha yang dikembangkan. Luaran dari kegiatan magang usaha adalah laporan secara tertulis oleh masing-masing tenant. 
Sesuai dengan jenis usaha yang akan dijalankan, maka lembaga-lembaga yang akan dilibatkan serta diajak kerjasama adalah dinas pemuda dan olahraga, dinas sosial, dinas koperasi, perindustrian dan perdagangan. Selain itu,sesuai dengan pangsa pasar dari luaran yang dihasilkan, maka kerjasama juga akan dilakukan dengan UKM. Khususnya di Kampus, maka akan dijalin kerjasama dengan laboratoratoium-laboratorium terkait usaha. Agar tujuan program yang dirancang tercapai, maka tim telah merumuskn langkah-langkah atau tahapan yang akan dilaksanakan. Tahapan ini terbagi atas 3 tahap yaitu, pelatihan, pendampingan dan penguatan.

1. Pelatihan Pelatihan yang akan dilakukan disesuaikan dengan kebutuhan calon tenant. Informasi ini akan diperoleh setelah diskusi pada tahap awal pelaksanaan kegiatan dilaksanakan. Jenis pelatihan akan mencakup pelatihan softskill dan hard skill. Softskil terkait penggalian potensi diri, sedangkan hard skill terkait pengetahuan kewirausahaan. Untuk memberikan materi, akan melibatkan pihak-pihak terkait pengembangan kewirausahaan. Antara lain indosenergi group dan Persatuan Ahli Massage Indonesia.

2. Pendampingan Pendampingan dalam hal ini dilakukan setelah pelatihan dilaksanakan. Jenis pendampingan dilakukan sesuai dengan kebutuhan yang diperlukan para tenant. Dalam hal ini, metode yang dilakukan adlah metode one man one mentor. Sehingga diharapkan mampu lebih mengakomodir permasalaham masing-masing tenant. Pendampingan dilakukan dengan prinsip pembinaan.

3. Penguatan Program penguatan dilakukan dengan 2 pola, yaitu pola lapangan dan pola insentif kebutuhan dasar. Pola lapangan yang dilakukan seperti magang insdustri, kunjungan industry dan studi banding industry. Sedangkan pola insentif berupa pemberian bantuan dalam bentuk pemberian modal usaha. Pemberian modal dilakukan apabila dianggap calon tenant memiliki potensi usaha yang menjanjikan untuk dikembangkan lebih. Pemberian modal berupa barang

\section{METODE PELAKSANAAN \\ Subyek Pengabdian}

Sasaran kegiatan ini adalah mahasiswa penerima program hibah Program Kreatifitas Mahasiswa Skema Kewirausahaan dan Program Kewirausahaan Mahasiswa. Selain itu juga mahaiswa yang berminat mengembangkan kewirausahaan(Sepriani et al., 2020)(Asnaldi, 2019)

\section{Tempat dan Lokasi Pengabdian}

Kegiatan ini dilaksanakan di Fakultas Ilmu Keolahragaan Universitas Negeri Padang. Dilaksanakan pada Agustus hingga bulan Oktober tahun 2020.(Sepriani et al., 2020)

\section{Metode Pelaksanaan Pengabdian}

Sesuai dengan tujuan dilaksanakan Pengabdian ini, maka pola pendekatan yang akan dilakukan menggunakan pola Participation Actions Learnig System (PALS). Pola ini merupakan pola dimana tenant berpartisipasi langsung dalam setiap program yang akan berikan. Setiap program kerja akan diikuti oleh setiap tenant. Program kerja yang dikembangkan dapat berupa pelatihan hardskill dan softskill kewirausahaan. Disamping itu, materi yang akan diberikan adalah materi-materi yang berkaitan dengan manajemen pemasaran dan pengelolaan keuangan serta administrasi sederhana pada bidang masingmasing. Metode pendekatan yang akan diterapkan seperti pelatihan kewirausahaan, magang pada industri mitra, pola pembimbingan, pengawasan terhadap wirausaha/usahawan pemula (tenant), teknik pembiayaan wirausaha/usahawan pemula (tenant), pola pemberian bantuan teknologi dan metode penyelesaian masalah. Untuk mencapai tujuan tersebut, maka pada program ini akan melibatkan beberapa instansi terkait pemecahan masalah yang dihadapi tenant, adapun instansi tersebut sebagai berikut: Untuk mencapai tujuan tersebut, maka pada program ini akan melibatkan beberapa instansi terkait pemecahan masalah yang dihadapi tenant.

\section{PELAKSANAAN KEGIATAN}

Pelaksanaan Kegiatan Untuk merealisasikan solusi yang telah ditawarkan untuk menyelesaikan masalah para tenant dalam kegiatan ini, maka pelaksanaan kegiatan PPK dilakukan melalui lima tahapan. Tahapan yang dilaksanakan mulai dari tahap penjajakan sampai dengan tahap produksi terkait produk yang dikembangkan para tenant. Tahap- tahap pelaksanaan kegiatan ini antara lain: a. Tahap survey atau penjajakan 
Journal Humanities: Jurnal Pengabdian kepada Masyarakat Volume 1, Nomor 2, Bulan Desember, 2020.

E - ISSN 2715-5471

Doi: https://doi.org/10.24036/jha.02.01.2020.11

Dalam tahap ini dilakukan penjajakan dan penentuan lokasi kegiatan pengabdian dan pemilihan/perekrutan calon tenant yang akan dilibatkan dalam kegiatan ini. Pola rekrutmen tenant pada kegiatan ini dilaksanakan dengan tiga bertahap. Tahapan penerimaan diawali dengan proses pendaftaran calon tenant. Dalam hal ini, calon tenant akan memasukkan surat pengajuan tenant dalam kegiatan ini. Tahap kedua adalah seleksi calon tenant. Dalam penyeleksian, calon tenant akan diwawancarai oleh tim. Tahap ketiga adalah pengumuman penerimaan calon tenant yang akan dibina melalui program PKK ini. Persyaratan utama pengejuan diri sebagai tenan adalah mahasiswa penerima PMW atau PKM yang telah, sedang dan akan berjalan. Dan bagi mahasiswa yang tidak mengikuti atau bukan berasal dari mahasiswa PMW dan PKM, wajib menyertakan gambaran jenis usaha yang akan dikembangkan.

b. Orientasi dan Diskusi

Orientasi dan diskusi dilakukan untuk mengidentifikasi permasalahan yang ada pada tenant dan mendiskusikan solusi yang dapat dilakukan untuk mengatasi masalah tersebut. Disamping itu, juga disusun rencana dan jadwal kegiatan bersama mitra. Jadwal kegiatan direncanakan selama tiga tahun. Mitra yang terlibat dalam kegiatan ini adalah Fakultas Ilmu Keolahragaan (FIK). Pemilihan mitra disesuaikan objek dan tujuan utama dilaksanakannya kegiatan ini, yaitu mahasiswa dan alumni Jurusan Pendidikan FIK UNP.

c. Tahapan persiapan pelaksanaan

Dalam tahap persiapan pelaksanaan ini ada beberapa kegiatan yang akan dilakukan. Kegiatan tersebut terbagi atas dua jenis, yaitu yang bersifat persiapan sarana dan prasana penunjang serta persiapan berupa administratif kegiatan. Persiapan berupa persiapan sarana prasarana seperti pemesanan bahan, komponen dan peralatan pendukung untuk pencapaian tujuan kegiatan tersebut antara lain. Sedangkan persiapan adminstratif seperti pengurusan izin kegiatan dan izin pemakaian labor. Jenis persiapan pun dibedakan atas kegiatan lapangan dan kegiatan ruangan. Kegiatan lapangan seperti izin kunjungan industri dan magang. Sedangkan persiapan ruangan lebih mengarah pada penyampaian materi yang dilakukan oleh pakar.

d. Tahapan pelaksanaan

Dalam pelaksanaan kegiatan ini akan dibedakan atas tiga jenis kegiatan, yaitu pelatihan, pembimbingan dan pendampingan. Pelatihan diberikan kepada tenant secara umum. Materi secara umum akan diberikan oleh pakarpakar akan dilibatkan dalam kegiatan ini, yaitu para pelaku wirausaha. Materi dilakukan dengan secara online mengguakan zoom meeting. Pembimbingan dilakukan dengan pola one group one mentor. Masing-masing anggota kegiatan akan dibagi dalam keahlian.. Dalam hal ini, pengelompokkan akan disesuaikan dengan jenis usaha yang dikembangkan. Pendampingan akan dilakukan dengan pola langsung dan tidaklangsung. Pola langsung dilakukan pada saat pertemuan yang akan dilaksanakan oleh masing-masing kelompok. Sedangkan pola tidak langsung disesuaikan dengan permaslahan yang dihadapi oleh masingmasing kelompok tenant.

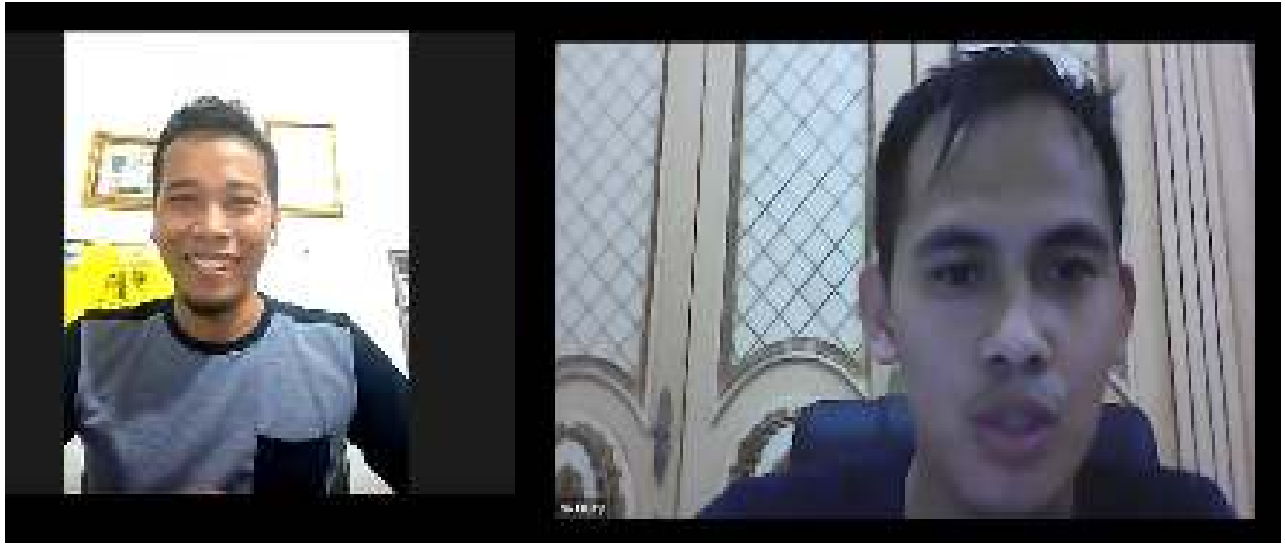

Gambar 1. Penyampaian Materi oleh Narasumber 
e. Tahapan monitoring dan evaluasi

Tahapan ini berupa kegiatan pendampingan dalam bentuk monitoring dan evaluasi atas pelaksanaan kegiatan pengabdian yang telah dilakukan. Kegiatan ini dilakukan bersama-sama oleh tim pengusul dan mitra dengan jadwal pelaksanaan sesuai dengan yang telah disepakati bersama.

\section{HASIL DAN PEMBAHASAN}

Berdasarkan perencanaan yang dirancang, mulai dari perencanaan, pelaksanaan yang terdiri atas kegiatan pelatihan, pendampingan dan evaluasi, maka secara keseluruhan kegiatan berjalan sebagaimana mestinya. Sesuai dengan tujuan pelaksanaan kegiatan ini, maka dalam pembahasan akan disampaikan beberapa hasil yang diperoleh sebagai berikut:

1. Peningkatan kemampuan peserta terkait softskill kewirausahaan

Secara keseluruhan dapat dinyatakan bahwa terjadi peningkatan terkait softskill kewirausahaan bagi para peserta kegiatan. Hal ini dapat dilihat dari timbulnya beberapa gagasan baru, ide-ide dalam berwirausaha yang diajukan peserta pada saat akhir kegiatan. Materi softskill yang diberikan pada peserta adalah materi terkait potensi diri terkait peluang kewirausahaan. Pemikiran-pemikiran serta ide-ide terkait potensi yang dapat dikembangkan dalam berwirausaha sambil kuliah. Selain itu, sisi lain yang dikembangkan terkait kemampuan softskill yang dikembangkan adalah kampuan terkait berkomikasi efektif serta berbagai hal yang diperlukan dalam beriwrausaha.

2. Peningkatan kemampuan peserta terkait hard skill kewirausanaan

Penekanan materi hard skill yang diberikan pemateri adalah terkait kemampuan menyusun bisnis plan, perencanaan usaha serta kemampuan dalam mengpromosikan usaha melalui berbagai media. Dari pelaksanaan terlihat peserta memahami setiap materi yang diberikan. Hal ini dapat dilihat saat diskusi dengan pemateri terkain rancangan draf usaha yang akan dijalankan. Berbagai jenis usaha, seperti jualan produk, jualan jasa dengan memanfaatkan potensi yang dimiliki. Sesuai dengan tujuan utama kegiatan ini adalah meningkatkan kemampuan peserta dalam memahai segala sesuatu terkati kewirusahaan, khususnya yang berkaitan dengan kemampuan manajerial bisnis, pengadministrasian, kualitas produk serta halhal lain yang berhubungan dengan kewirausahaan

\section{KESIMPULAN}

Berdasarkan tujuan yang telah ditetapkan pada awal kegiatan, maka dapat disimpulkan bahwa: Terjadi peningkatan kemampuan soft skill dan hard skill peserta kegiatan terkait kewirausahaan.

\section{DAFTAR PUSTAKA}

Asnaldi, A. (2019). Panduan Pelatihan Komponen Motor Ability Bagi Pelatih Lemkari Dojo Angkasa Lanud Padang. ResearchGate.

https://www.researchgate.net/publication/332709190_Panduan_Pelatihan_Komponen_Motor_Ab ility_Bagi_Pelatih_Lemkari_Dojo_Angkasa_Lanud_Padang

Sepriani, R.-, Eldawaty, E., Asnaldi, A., Wahyuri, A. S., \& Kibadra, K. (2020). Pembuatan Jamu Serbuk Instan Berbasis Tanaman Obat Keluarga (Toga) Bagi Ibu-Ibu Pkk Di Kelurahan Tarantang Kecamatan Lubuk Kilangan Kota Padang. Jurnal Berkarya Pengabdian Masyarakat, 2(1), 49-55. https://doi.org/10.24036/jba.v2i1.51

Anton K, Nurul I Jauhari. 2017. Pengembangan Tes Kelentukan Berbasis sensor. FIK UNP. Laporan Penelitian

http://www.antarasumbar.com/berita/183756/33-kelompok-mahasiswaunp- lolos- programmahasiswa-wirausaha.html. 20146. 33 Kelompok Mahasiswa UNP Lolos Program Mahasiswa Wirausaha. 
Journal Humanities: Jurnal Pengabdian kepada Masyarakat Volume 1, Nomor 2, Bulan Desember, 2020. E - ISSN 2715-5471

Doi: https://doi.org/10.24036/jha.02.01.2020.11

kemenristekdikti sebagai institusi pemerintah yang menerapkan pengelolaan keuangan badan layanan umum.

Nurul Ihsan, Dkk. 2018. Instrumen Kecepatan Tendangan Pencak Silat Berbasis Teknologi.

Publication Name : Jurnal Sosioteknologi 17 (1), 124-131 vol. , 2018

www.ganto.or.id/berita/1312/unp-resmi-jadi-blu.html. UNP Resmi Jadi BLU. Diakses tanggal 20 Agustus 2018

www.ganto.or.id/berita/1689/pmw-ciptakan-mahasiswa-“job-creater”.html . PMW Ciptakan Mahasiswa Terampil. 